\title{
Business Model Innovation in the Internationalization of SMEs: The Role of Causation and Effectuation
}

\author{
Agnes Asemokha \\ LUT University, \\ Finland \\ agnes.asemokha@lut.fi
}

\author{
Jackson Musona \\ LUT University, \\ Finland \\ jackson.musona@lut.fi
}

\author{
Ali Ahi \\ University of Helsinki, \\ $\begin{array}{ccc}\text { Finland } & \text { Finland } & \text { Finland } \\ \text { mohamadali.ahi@helsinki.fi } & \text { lasse.torkkeli@lut.fi } & \text { sami.saarenketo@lut.fi }\end{array}$ \\ Lasse Torkkeli \\ LUT University, \\ $\begin{array}{ccc}\text { Finland } & \text { Finland } & \text { Finland } \\ \text { mohamadali.ahi@helsinki.fi } & \text { lasse.torkkeli@lut.fi } & \text { sami.saarenketo@lut.fi }\end{array}$
Sami Saarenketo
LUT University, \\ $\begin{array}{ccc}\text { Finland } & \text { Finland } & \text { Finland } \\ \text { mohamadali.ahi@helsinki.fi } & \text { lasse.torkkeli@lut.fi } & \text { sami.saarenketo@lut.fi }\end{array}$
}

\begin{abstract}
Small- and medium-sized enterprises (SMEs) undergo different life cycle transitions that affect their business models (BMs) as they seek new to enter foreign markets. Although international entrepreneurship (IE) scholars have recognized the relevance of exploring the creation and growth of entrepreneurial firms, there is a dearth of studies linking how the key decision-makers influence their business model, especially as they pursue internationalization success. This study aims to respond to these gaps in the research by examining the nexus of effectuation and causation (decision logic) and how the combined effects of these logics influence business model innovation (BMI) as SMEs internationalize. In reviewing the existing literature on these concepts, we develop theoretically driven propositions that link business model innovation and decision-making logic in international entrepreneurship that can be subsequently tested with empirical data in the future. This study contributes to the literature on decision-making and business model innovation. It also links two streams of the research, which, to our knowledge, is limited. Moreover, the study is unprecedented in the international entrepreneurship domain.
\end{abstract}

\section{Introduction}

The common goal of setting up a business is to be profitable and improve competitive positioning and improved performance both at home and abroad [1]. As a result, companies that seek to internationalize are faced with the vital task of re-configuring their business models and matching their activities to manage uncertainty and effectively exploit recognized opportunities [2, 3]. Entrepreneurs are also expected to be knowledgeable enough to predict the future and adequately coordinate their resources and capabilities [4] to achieve successful internationalization [5, 3]. However, because internationalization is a complex and daunting task, especially in small and medium enterprises (SMEs), managers need to assess the market situation, make sound judgments and re-configure their business models to ensure that they will thrive in complex and uncertain markets $[6,7]$.

Decision-making is essential because it provides useful insights into how firms adapt their business models (BM) and orchestrate existing resources and capabilities to create value for customers and stakeholders as they operate or veer toward international markets $[6,7,8]$. Therefore, managerial decision logic influences both the firm's BM and the strategies adopted in new market operations [8]. Previous studies highlighted that firms' decision-making and business models are expected to be interlinked $[9,10,11,12]$, revealing that the exploration of managerial choices may explicate how and why companies internationalize and the implications for BMs and vice versa [7]. As a result, we give credence to the notion that firms' BM and entrepreneurial decision-making are interlinked [13, 3]. However, because they have been examined separately, the dynamics of decision logic and business models have not been studied, particularly in the IE/IB domain. Previous studies point out that emerging perspectives in IE, such as BMI [14, $15,16,17,18]$ and decision-making logic, are valuable concepts in explaining the behavior and actions of SMEs that undergo internationalization [4].

Scholars also advocate that IE research would be further enriched by adopting alternative frameworks and perspectives that provide a more profound and complementary understanding of entrepreneurial activities, such capabilities, BM dynamics and changes occurring in the firm, as well as other activities influencing the lifecycle of the firm $[19,20$, 21]. Studies have shown that firms with access to financial incentives, valuable network partners, enthusiastic employees, and effective leaders support the journey of business growth and long-term success [22, 23, 24]. Scholars have added that a firm's success lies in the entrepreneur's contextual role, orientation, motivations, and how their means and actions support the achievement of set goals [4, 14]. Therefore, understanding decision-making logic and entrepreneurial behavior, especially regarding international market opportunities, would help advance the IE and business model innovation (BMI) research $[14,25,26]$. The reason is that managerial decision-making and the ability to change BMs innovatively are valuable in the BM development and longterm success of a venture. By exploring entrepreneurial decision-making, we gain further insights into how SME actions influence opportunities (i.e., identification and discovery) and the choices made to execute them, which affects BMs adopted in foreign markets [8, 16, 12, 23].

This study explores SMEs' decision-making (i.e., effectuation and causation), as well as the combined effects of these decision logics on BMI's overall role in creating, delivering, and capturing value in SME internationalization. Effectuation and causation provide a useful lens for exploring international entrepreneurial firms, the effectiveness of their managerial choices [16, 13], and their business models [23, 24, 27]. Most previous studies have focused on either causal or 
effectual logic to examine international entrepreneurial behavior and performance $[28,29,30,31,32]$. However, the implications of the combined effects of effectual and causal decision-making logic have been left unexplored.

This study both draws on and contributes to the IE domain literature by exploring theoretical linkages between BMI and the decision-making logic(s) of effectuation and causation. It illustrates the role of decision-making logic and its influence on the BMI of internationalizing SMEs and, as a result, provides theoretical propositions. We continue by reviewing the relevant literature on decision-making logic and the BMI of internationalizing SMEs.

\section{Literature Review}

\subsection{Business models and business model innovation}

Business models have gained prominence in academia and practice since the 1990s. Several studies have attempted to describe, theorize, validate, and link BMs to other disciplines $[33,34,35]$. Despite the increasing amount of research on business models, there is still insufficient attention in the literature to theorizing and borrowing ideas from neighboring disciplines to advance $\mathrm{BM}$ research [33]. However, converging descriptions have defined a $\mathrm{BM}$ as the design or architecture of a firm's observable constellation of activities that are dedicated explicitly to value creation, delivery, and capture mechanisms [7]. The value creation mechanisms in BMs reflect organizational decisions that define resource allocation, identify and capitalize on new business opportunities, and introduce new products and services in the market [35]. Value proposition deals with how the firm provides value to its customers [7]. Value capture focuses on the way the business makes profits [36].

BMs reflect entrepreneurial decisions, strategic decisions, and operational implications [9, 33, 35] as entrepreneurs discover and implement new opportunities [37, 38, 3]. Hence, a firm's BM manifests an idea that conforms to an envisioned architecture and embodies how entrepreneurs create and deliver and capture value [7]. Researchers have pointed out that entrepreneurial orientations and managerial approaches to opportunities and decisions greatly influence the degree of success that such businesses can accomplish, especially across national borders [24, 25, 26]. Nonetheless, it is crucial to note that a $\mathrm{BM}$ is unique to each organization. Moreover, the dimensions of BMs consist of several interrelated building blocks that form different configurations that can be used to evaluate change [7] within the firm. However, a change in one dimension may not have a direct or immediate impact on another dimension. Empirical research on BM change configurations could provide further insights into a firm's working logic [14, 20,27]. BMs nonetheless provide dynamic insights and interpretations of management activities and decision-making [16]. Therefore, changes that occur in BMs can provide an in-depth understanding of management and entrepreneurial reactions to environmental changes, and they are related to a firm's operations, strategy, and internationalization activities $[27,23,8]$. The exploration of business model innovation (BMI) leads to the evolution and development of BM beyond novel products and services.
Hence, by innovating their BMs, SMEs develop unique capabilities of satisfying stakeholders while sustaining competitive advantage.

Previous studies have shown that managerial decisions influence how organizations innovate, conform, and develop the core processes necessary for internationalization success [23], thereby reinforcing that business models are powerful tools that can be adopted to hypothesize and decide customer wants (e.g., products and transaction methods). However, entrepreneurs can dynamically combine value mechanisms to ensure that their customers are satisfied, and the firm's goals are achieved [7]. Thus, entrepreneurs may leverage the business model's flexibility to accommodate market uncertainty and the changes $[20,21]$ required in a company's day-to-day activities, which influence value creation and appropriation and have implications for the business agility and success of the firm $[39,20,21]$. Thus, by examining a company's BMI activities, we can rationalize its ongoing changes and further examine the choices made within and beyond the decision-makers' bounded rationality as well as the implications for business success [20]. Figure 1 provides an illustration of the research framework and propositions.

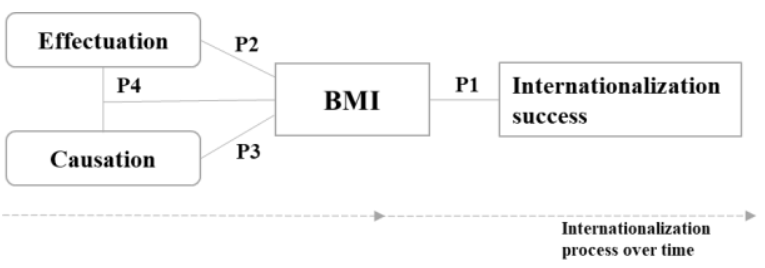

Figure 1. Research model (framework of the study)

\subsection{Internationalization of SMEs and Business Model Innovation}

Regarding the future of IE research, scholars have highlighted that IE and IB research has made great strides because it offers valuable opportunities for explaining complex phenomena using existing and emerging strategy theories and frameworks [3]. Thus, drawing on the IE context, we aim to gain theoretical insights into how entrepreneurs' activities may affect the BMs of SMEs when they internationalize. Moreover, we consider that the BMI perspective is a persuasive contributor and outcome of the international entrepreneurial process because it allows us to rationalize the strategic choices and internationalization activities of SMEs, which are known to be complex.

The research on BMI has provided scholars with a novel way to harness and interpret real-world (i.e., firm-level) operations and managerial choices, which have not usually been explored in tandem [40]. The exploration of BMI activities allows for the practical observation of change, such as how the company improves its existing BM or develops new $[11,41,42]$ or complementary processes, products, and organizational innovation [33, 40]. Evidence from both academics and practice has shown that top business executives prioritize BMI as an alternative or complement to product innovation, as well as to combat competitive pressures and cope with uncertainties as they internationalize [34, 43, 44]. Therefore, BMs are a competitive tool used to incrementally or radically innovate the core processes [20] of the 
organization and enable viable and remunerative business decisions [35, 44, 45]. Moreover, previous studies have confirmed that BMI (i.e., superior to product or technology innovation) contributes to the success, competitive advantage, and success of internationalizing SMEs [23].

As firms internationalize, managers must make strategic choices and develop dynamic BMs that support an effective transition into new markets and manage uncertainty [46]. Scholars have identified that managers in the vanguard of core activities support decisions (e.g., information gathering, customer engagement, managing partner and supplier relationships, and other operational activities) that are critical for successfully shaping the value configurations necessary for managing uncertainty in the internationalization process of SMEs [28, 34]. The SME manager's role, orientation, and choices are catalysts that reinforce or undermine a company's innovation and growth trajectory [23]. Hence, the firm's working logic is a resolute or predetermined consequence of managerial choices, and a firm's strategic choice is mirrored and interpreted through its BM [47].

SME managers engage in BMI to thrive in international markets $[8,26]$. However, to manage business interactions and make strategic choices regarding a BM or select stakeholders' interactions, managers need to experiment or test their business activities to ensure that they are scalable, repeatable, and suitable for the BM [21,3]. Thus, BMI is particularly valuable in providing managerial initiatives and decisionmaking about firm operations and internationalization activities [44, 45, 46]. It is also useful in helping managers to predict or control uncertain market conditions, which is valuable for profitable outcomes [44, 4]. Thus, we surmise that managers who prioritize BMI in their decision-making provide a unique competitive approach through which firm strategies and operations cannot be easily replicated [47, 48, 7], thereby making the BM of internationalizing SMEs a competitive tool that can accommodate the continuous adaptation of firm activities for a long-term competitive advantage $[49,9,23]$ :

P1: SMEs that engage in business model innovation can internationalize better and quicker than those who do not engage in business model innovation.

\subsection{Business model innovation and effectuation logic in SME internationalization}

Effectuation is a logic-based on non-predictive control, and it is defined as means-driven, logic-driven, or emergent planning [4]. It is based on the selection of alternative principles. Effectual thinking considers heuristic processes and managerial interactions to achieve a set of means [50,4]. Internationalizing firms that adopt effectuation tend to be more flexible in their strategy formulation and implementation and their business (model) activities in general [13, 23, 51]. For that reason, they may repeatedly experiment with different market scenarios and BMs before selecting a suitable and specific BM design [47, 51, 52]. The concept of affordable loss is highly integrated into the orientation of effectuation [6, 53]. SMEs that adopt effectual thinking tend to be more riskaverse and incrementally internationalize or invest than their casual counterparts $[6,13,1]$. Entrepreneurs who adopt effectuation are often more experienced and creative, and they tend to innovate their BMs incrementally based on market dynamics or even by chance in proportion to $[16,8]$ organizational and/or stakeholder demands [53]. In summary, effectuation logic leverages strategic relationships, resources, knowledge, and capabilities to foster the exploitation of market contingencies and opportunities [54, 55, 13]. In other words, they tend to be proactive and do not necessarily stick to strict plans or the status quo because of their experience and creativity and the need to be ahead of the competition. Examples of this kind of firm are software or platform companies where technology and consumer interests are continually changing, and entrepreneurs have no choice but to innovate daily to remain relevant. However, some studies have argued that effectual logic is often emphasized in the early stages of new venture creation and gradually transitions to causal strategies in later stages $[30,22]$. However, we predict that SMEs that follow effectuation logic in their decisionmaking processes are likely to innovate their BMs as they internationalize:

P2: Effectual decision-making logic in international SMEs leads to increased business model innovation.

\subsection{Business model innovation and causation logic in SME internationalization}

Causation is a rationale that involves developing a strategy from a starting point, planned strategy, or destination goal [4]. Sarasvathy noted that the role of decision-making logic is more visible due to environmental and market uncertainty [4]. Briefly, causation is the decision-making rationale of planning ex-ante, while effectuation is based on ex-post and emergent strategies [13, 31]. Previous studies demonstrated the relevance of causation in actions based on preexisting market information and rational entrepreneurial choices [50, 13]. Causal decision-making was found to allow managers to make calculated plans regarding internationalization choices [8] to optimize their resource flows and achieve predetermined goals $[51,4]$. Causal logic involves making predictable goal-driven plans and exploiting knowledge and resources to capitalize on future opportunities and gain a competitive advantage [50]. The incentive for causation is based on the premise that firms initiate deliberate and analytical measures to minimize the unexpected effect [4]. Causal approaches to BMI provide a preemptive orientation to business, which has not been extensively explored in the research, especially in internationalizing entrepreneurial firms.

Entrepreneurs who causally approach decision-making tend to be highly capable of predicting the future [3]. However, some firms may adopt causation logic because the entrepreneurs have limited international experience and may want to minimize risks [13]. Nonetheless, entrepreneurs who use the causal approach quickly exploit opportunities; thus, they tend to closely monitor their external environment to generate new information about future developments, which is valuable for potential BMI and BM development [1]. The goal of implementing causation in a firm's BMI aims at augmenting environmental contingencies and uncertainties in international markets $[39,1]$. Causation has been seen as an enhancer of BMI [1]. This finding contributed to the BMI 
research by showing that managers may implement causation to support opportunity identification and international market decisions and ensure that the firm (i.e., value proposition creation and capture) is well-targeted to the intended market or segments. Entrepreneurs may also use the marketplace's feedback to refine their product or service [16]. Therefore, internationalizing SMEs driven by causation logic are likely to be successful in internationalization activities when they increasingly innovate their business model:

P3: Causal decision-making logic in international SMEs leads to increased business model innovation.

\subsection{Business model innovation: the role of effectuation and causation in SME internationalization}

Numerous factors may influence an entrepreneur's choice of adopting either causal or effectual logic. Some reasons include experience, funding, organizational change, and so on $[13,25,18,53]$. Advances in technology and globalization have increasingly blurred industrial and market-entry barriers. More than ever before, firms can interact with customers in real-time and provide them with services from anywhere in the world [48]. Thus, allowing managers to rethink and redesign their BMs because technological advances make it possible for firms to reach customers swiftly and, consequently, speed up the exploitation of international opportunities. Moreover, because of BMI's immeasurable importance for competitiveness and growth, which are a strategic priority for managers in diverse industries and a source of above-normal returns $[33,27]$, SMEs continuously seek to innovate their BMs [23].

Examining the role of decision-making as SMEs cross borders provides a deeper understanding of entrepreneurial actions as a function of choices, which gives structure to a firm's process (i.e., BM) and informs managerial measures to approach market opportunities, especially in dynamic and uncertain environments $[4,53,10]$. Varying perspectives have been used to explain how executive decisions shape a firm's future. For example, some studies have justified that the managerial capability to sense, seize, and transform an opportunity has led firms to causally amplify their efforts in improving their core activities, thereby leading to BMI [22]. Thus, causal initiatives tend to reduce uncertainty and support the impetus for BMI and predictive profitably. Moreover, some studies have shown that entrepreneurial firms may design an artificial system or engage in BMI to attain a specific goal or commitment to the future [19]. Other studies found that instead of analytical planning, through trial and error or experimentation [51], they may engage in BMI to quickly capitalize on an actual or latent opportunity or, better still, test the lucrativeness of the opportunity [22]. However, despite these distinctions, effectual logic is often emphasized in the early stages of new venture creation and gradually transitions to causal strategies in later stages [30].

Managers act as agents of change [20] and use their BMs as decision-making tools, either effectually or causally, to redesign or change their operations to satisfy a situation, especially when they enter or consider internationalization [8, 9]. However, we recognize that the entrepreneur's or manager's role is pivotal because of the bounded rationality of human nature; an entrepreneur will make decisions based only on his or her knowledge or capability. It may be difficult to demarcate the tensions between effectuation and causation regarding entrepreneurial behavior, especially when SMEs seek to enter foreign markets [10, 24]. Therefore, a firm's decision may alternate between both logics depending on the situation at hand. Decision-makers may also have varying sensitivities to how they perceive the future, orchestrate resources, and evaluate risks and uncertainty [24, 52]. Thus, both effectual and causal logics provide in-depth insights into strategic orientations, responses to opportunities, entrepreneurial action orientations, partnerships, and alliances, all of which are vital in understanding entrepreneurial and SME internationalization behavior [16, $56,57,58]$.

Moreover, scholars have suggested that both effectuation and causation can function as complementary or alternative cognitive entrepreneurial approaches used in new venture development $[10,24,56]$. Some studies even view the combined use of effectuation and causation as an "organizational ambidexterity" [59], i.e., the ability to pursue two things simultaneously [60]. Some studies highlight organizational ambidexterity as a firm's capability to efficiently manage routines or daily business demands while simultaneously adapting to environmental changes [61]. Scholars also debate that the combined usage of both logics can foster holistic knowledge mapping of an entrepreneur's decision making [62], arguing that the use of a single logic may result in inconsequential reasoning and the inability to compare different options [59]. However, scholars advocate for pursuing both logics to leverage their complementarities and enhance performance $[59,63]$.

This suggests that the sub-constructs of effectuation and causation are not necessarily in absolute opposition to one another; instead, they could be viewed in combination or orthogonally (i.e., similar to satisfaction and dissatisfaction) $[10,24,56]$. Hence, exploring BMI and the combined and/or alternation of effectuation and causation could be valuable in better explaining SME internationalization activities [10, 39, 1]:

P4: The more that internationalizing SMEs combine effectuation and causation logic in their decision-making, the greater their engagement in business model innovation.

\subsection{Business case}

This case involves how a Finnish SME (Company Alpha) expanded into international markets and how the managers approached decision-making as their firm ventured across borders. Company Alpha is an online business that provides streamlined e-commerce solutions and services for clients by providing them with custom solutions to enable them to sell their products in international markets. Its BM is centered on bridging international boundaries and providing custom solutions to help clients export Finnish products conveniently to international markets. Alpha's main value proposition is to act as an intermediary for business clients and provide services 
and relevant information to customers to achieve cross-border trading of their products and services online. Their business solutions include e-commerce, sales management, logistics, and consulting, mainly in Russia, Japan, and China. An example of their mode of operation is that Alpha offers its clients the option of entering the Russian market by building their online store or creating a space for them in the Russian multi-seller platform. For example, Alpha created solutions for its clients (i.e., retailers) by co-creating one of the largest Japanese online market platforms.

The company also works to gain more cooperation with other online marketplaces. The company has expressed interest in expanding its client base into the Nordic countries, parts of Europe, and North America. However, their immediate focus is to support clients in the home market to sell products in the Russian, Japanese, and Chinese markets because of their experience working with partners in these specific markets. Alpha has vast network relationships and consistently collaborates with partners to develop international and local partners, such as partnerships with local logistics providers (i.e., the home and host countries) at both ends of their customer scale. The company also provides an all-in-one package that allows clients to internationalize successfully by leveraging services (e.g., logistics, marketing, local channels, and consultation), thereby minimizing significant internationalization investment costs, which is crucial in facilitating international activities between clients across borders. The founders' expertise was fundamental to the creation of the company. The founders were experts in different professional fields, such as international marketing and logistics. Thus, the founders' combined expertise provided the foundation in which the BM and the firm's core services are embedded. Table 1 shows findings based on Alpha's internationalization of its operations in Japan, China, and Russia. Table 1 includes excerpts from responses about the company's decision-making and how the entrepreneurs approach international opportunities. Although we did not analyze the case in-depth, we reflected on and identified how the entrepreneurs leveraged their resources and capabilities, the consequences of their entrepreneurial actions, and how they were manifested in changes to the company's BM.

Table 1. Business model changes and decision-making (Case Alpha)

\begin{tabular}{|c|c|c|}
\hline Useful quotes & $\begin{array}{l}\text { Business } \\
\text { model changes: } \\
\text { Connecting BMI } \\
\& \\
\text { internationalizat- } \\
\text { ion activities }\end{array}$ & $\begin{array}{l}\text { Decision- } \\
\text { making } \\
\text { logic: } \\
\text { Effectuati- } \\
\text { on and } \\
\text { Causation } \\
\end{array}$ \\
\hline \multicolumn{3}{|c|}{ New customer, value offering, and customer base } \\
\hline $\begin{array}{l}\text { Customer push and opportunity } \\
\text { sensing } \\
\text { [The Japanese company] contacted } \\
\text { us [....] They started to discuss with } \\
\text { us that they would like to have } \\
\text { Finnish products [....] We didn't } \\
\text { actually think about Japan at this } \\
\text { moment at all [...] Then we } \\
\text { changed our plans that "OK, now } \\
\text { we do this" [....] We were forced to } \\
\text { change our strategy in this kind of } \\
\text { opportunistic way in a point when } \\
\text { we saw that now this might work } \\
\text { and let's do it." }\end{array}$ & $\begin{array}{l}\text { Establishing a new } \\
\text { market presence } \\
\text { by opening a new } \\
\text { target market base }\end{array}$ & Effectuation \\
\hline $\begin{array}{l}\text { Founders' (past) experience and } \\
\text { related capabilities } \\
\text { "For us, Russia has a very long }\end{array}$ & $\begin{array}{l}\text { Generating } \\
\text { knowledge and } \\
\text { creativity based on }\end{array}$ & Effectuation \\
\hline
\end{tabular}

\begin{tabular}{|c|c|c|}
\hline $\begin{array}{l}\text { history. Because my previous } \\
\text { company was dedicated to Russian } \\
\text { internet marketing, this current } \\
\text { company is the spin-off company of } \\
\text { that. [...] We found that this kind of } \\
\text { e-commerce solution is needed." }\end{array}$ & $\begin{array}{l}\text { previous } \\
\text { international } \\
\text { personal } \\
\text { experience }\end{array}$ & \\
\hline \multicolumn{3}{|c|}{ Juxtaposition (iteration) in value capture and delivery } \\
\hline $\begin{array}{l}\text { Developing/establishing a } \\
\text { marketing plan to seize the } \\
\text { recognized opportunity } \\
\text { "Also, the idea of this web page is } \\
\text { that this is the channel through } \\
\text { which the companies can } \\
\text { contact us. So, we started } \\
\text { discussing this web page..." }\end{array}$ & $\begin{array}{l}\text { Developing of a } \\
\text { new channels by } \\
\text { creating an online } \\
\text { presence to reach } \\
\text { existing and new } \\
\text { customers. }\end{array}$ & $\begin{array}{l}\text { Effectuation } \\
\text { and } \\
\text { Causation }\end{array}$ \\
\hline $\begin{array}{l}\text { Devising a pathway to transform } \\
\text { sensed international opportunities } \\
\text { and utilizing complementary } \\
\text { assets/capabilities to capitalize } \\
\text { on the realized opportunity } \\
\text { "...Now I'm planning this new } \\
\text { marketing plan. I'm defining it. The } \\
\text { core of this plan is that we should } \\
\text { have a good web page where we } \\
\text { can present our services, and the } \\
\text { references tell about us and this } \\
\text { kind of thing... and other channels } \\
\text { which we're going to use are } \\
\text { Twitter, LinkedIn, Facebook, } \\
\text { YouTube, as well. They are the } \\
\text { channels that are leading the traffic } \\
\text { to our web page." }\end{array}$ & $\begin{array}{l}\text { Formulating } \\
\text { competitive new } \\
\text { channels and } \\
\text { strategies to } \\
\text { identify and reach } \\
\text { new customers } \\
\text { markets }\end{array}$ & $\begin{array}{l}\text { Effectuation } \\
\text { and } \\
\text { Causation }\end{array}$ \\
\hline \multicolumn{3}{|c|}{$\begin{array}{c}\text { Value creation and opportunity execution based on core competence and } \\
\text { partner networks }\end{array}$} \\
\hline $\begin{array}{l}\text { Practical knowledge and } \\
\text { expertise adapted to transforming } \\
\text { opportunities } \\
\text { "We already have a very wide } \\
\text { range of expertise in the } \\
\text { background of our company [....] } \\
\text { I manage marketing with my } \\
\text { partner. The present CEO is a } \\
\text { logistic expert; our partner trades } \\
\text { the software we use on our } \\
\text { platform [....] All these experts } \\
\text { (working) together provide all we } \\
\text { need." }\end{array}$ & $\begin{array}{l}\text { A wide range of } \\
\text { expertise and } \\
\text { tactical } \\
\text { capabilities in the } \\
\text { background of the } \\
\text { founders favors } \\
\text { innovation and the } \\
\text { development of } \\
\text { new ideas. }\end{array}$ & $\begin{array}{l}\text { Effectuation } \\
\text { and } \\
\text { Causation }\end{array}$ \\
\hline $\begin{array}{l}\text { Strategic planning and approach to } \\
\text { international opportunity; based on } \\
\text { accumulated experiences and } \\
\text { market knowledge. Leveraging past } \\
\text { relationships, partners, and } \\
\text { networks to execute the idea. } \\
\text { This company was created in } \\
\text { connection with our Russian } \\
\text { networks from our previous [....] } \\
\text { This is the long history of these } \\
\text { connections [....] However, the core } \\
\text { idea is that we do not want to grow } \\
\text { [...] the platform too much [...] By } \\
\text { keeping it as light as possible [...] } \\
\text { and leveraging our networks, we } \\
\text { can keep fixed costs low at the } \\
\text { moment. }\end{array}$ & $\begin{array}{l}\text { Leveraging } \\
\text { existing networks } \\
\text { and capabilities } \\
\text { and experience to } \\
\text { implement new } \\
\text { ideas to create and } \\
\text { capture value and } \\
\text { minimize risks } \\
\text { and uncertainty. }\end{array}$ & $\begin{array}{l}\text { Effectuation } \\
\text { and } \\
\text { Causation }\end{array}$ \\
\hline
\end{tabular}

\section{Discussion}

This study examined the relationship between SME decision-making based on effectuation or causation logic, BMI, and the implications for successful SME internationalization- Previous studies [24, 1] have elaborated on the positive relationship between BMI and SME internationalization. However, in the current study, we established the relevance of entrepreneurial decision-making for the BMI and IE literature, which has been little studied. We also stated propositions of effectuation and causation and how they related to BMI. We contended that despite the differences between effectuation and causal logics, in internationalization, the logic used in managers' decision-making may overlap 
depending on the firm's context or situation. We also emphasized the need to examine the combined effects of decision-making logic and BMs in the IE domain.

Based on the case of Company Alpha, our study established that varying trends and market requirements or situations (e.g., founder's experience and network relationships) determined how managers reacted to international market opportunities [16, 64]. Thus, entrepreneurs could use their BMs as narratives or tools to communicate how they want to manage and organize operations $[16,55,10]$. In other words, in dynamic and rapidly changing environments, firms need to change their BMs, routines, and processes, both actively and flexibly [19, 64]. This can occur by combining effectual logic and causal logic to manage the risks associated with this dynamism and enhance the firms' competitive position in international markets. Our study also found that changing market dynamics and factors may influence a single or combination of a BM's value mechanisms [8, 17]. However, entrepreneurs must invent and identify unique ways to predict and control their future through decision-making processes, which do not occur in a vacuum $[65,54,31,4]$. Instead, decision-making logics are expected to reveal how internationalizing ventures manage to grow and survive despite the challenges they may face, such as liability of newness or smallness, limited resources, and capabilities $[66,16,12]$.

We also identified that several factors (e.g., firm age, industry category, internationalization activities, government regulations, and policies) might influence managerial decisions on value creation and capture activities across borders $[8,9]$. However, adopting a $\mathrm{BM}$ as a strategic and competitive tool provides useful pillars and-coping mechanisms for strategic decision-making and guidance on the initiatives a firm should take in its daily operations $[67,31$, $35,10]$. In short, BMs are useful mechanisms that consider internal and external consistency and strategic choices, which may encourage managers to make better and holistic decisions as they internationalize $[9,10,67]$. Thus, our first proposition which states that SMEs that engage in BMI can internationalize better and more quickly, which may positively affect their internationalization success.

The second proposition stated that effectual decisionmaking logic in international SMEs strengthens BMI. The reason is that effectuation may support the creation and discovery of international opportunities [31, 1]. Moreover, SMEs may adopt effectuation in their $\mathrm{BM}$ as a coping mechanism or a strategy for thriving in and surviving market complexities [35]. Effectuation also fosters proper utilization and orchestration of firm resources and supports strategic decisions in favor of the future. In other words, decisions (e.g., regarding product or technology innovation, partners, and customers) are made intuitively to control future circumstances rather than predict them $[53,3]$. These findings align with previous BMI studies that suggested that managers tend to proactively take initiatives that allow them to control market situations and trends, especially to capitalize on international opportunities [55, 42, 26, 24].

Our third proposition stated that causal decision-making logic in international SMEs strengthens BMI. As a cognitive and entrepreneurial activity, causation logic builds on a firm's ability to predict the future [4]. Managers in SMEs that are approaching internationalization decisions using causation logic make more calculated and goal-driven decisions. Thus, they are more likely to leverage premeditated ideas and plans to modify BMI initiatives and value creation and capture mechanisms to explore or exploit business opportunities to increase profits in selected markets [8, 13]. As mentioned earlier, internationalizing SMEs may use causation approaches in their BMs to actively address uncertainty. They may do so through predictive-oriented planning. For example, managers make business plans or calculate market and competitive analyses to ensure and increase their knowledge of the status quo and ensure that expected returns are achieved $[13,4,1]$. Entrepreneurs with predictive capabilities, alertness, and knowledge about adapting their repeatable core processes are valuable in BMI. However, in inexperienced early internationalizing firms, some predictive approaches may be utilized as coping mechanisms [35] and adapted by entrepreneurs to stay ahead of market trends and identify latent customer needs.

In developing our fourth proposition, we argued that the higher the combined effectual and causal logic in an international SME, the higher the extent of BMI. In line with previous studies $[10,25,39])$, we considered that effectuation and causation could co-exist [59]. Furthermore, explorative decision-making (i.e., effectuation and causation logics) is valuable in BMI and international performance. BMI has unique advantages that are difficult to replicate, leading to lasting competitive and improved international performance advantages [7, 33]. Several previous studies found that various factors, such as technology innovation, market-entry decisions, location decisions, sustainability requirements, and digitalization decisions, affected SMEs' BMI when they entered foreign markets [8, 14, 17, 64]. Although it was not explored in-depth, another interesting addition to this study is that in our modern era (especially in times of uncertainty), different factors such as digitization, technological advances, analytical databases, and artificial intelligence are pushing firms to move ahead of their time [68]. Thus, more than ever, especially in the era of the "new normal," artificial intelligence and other digital and technological tools predict human behavior, leading to the cannibalization of customer information and firms regardless of their size. For the first time in human history, we can predict customer demand. Thus, predicting and controlling market economics, which leads to drastic BMI, and creating uncontested market spaces are areas that should be explored in future research.

Furthermore, because decision-making is a cognitive process centered around varying degrees of uncertainty, knowledge gaps, and/or decision-makers' bounded rationality, we argue that it is not an option for firms or business owners to stay redundant in continual anticipation of successful market outcomes [69]. Instead, entrepreneurs who-pursue growth via experimenting or engaging in BMI have the potential to transform their products and services, serve dynamic global markets, and survive uncertainty [70]. Entrepreneurs are also required to have flexibility in their decision-making (i.e., they should be able to make either effectual or causal decisions) [25] and implementation skills to swiftly and effectively tackle business decisions to reach implementable solutions for successful internationalization [8, 10]. Thus, because of the uncertainties in foreign market 
frontiers, predicting and controlling aspects of a BM and the related processes are valuable in robust and effective decisionmaking.

\section{Theoretical Contribution and Practical Implications}

International entrepreneurship is a novel field of study that researchers are continually seeking to understand. Scholars have established that decision-making provides an alternative theoretical means of describing and extending the understanding of international entrepreneurial actions $[4,3$, 25]. Thus, by combining insights gained from BM changes and decision-making theory, we extend our understanding of the reasons entrepreneurs do what they do, especially when they internationalize.

First, the study contributes to the stream of IE literature that outlines the role of decision-making logic and business models in this domain. Previous studies have suggested that BMI and decision-making logic in the IE domain should be interlinked [10, 1]. Moreover, scholars have suggested that studies should examine entrepreneurial decisions and the role of human agency to understand entrepreneurial behavior [4, 31, 12]. Moreover, entrepreneurs' decision-making logic provides comprehensive insights into behavioral uncertainties, goal ambiguities, and their enactments in uncertain international markets, which has not been extensively explored $[71,12,16]$. The findings of our study demonstrated that, theoretically, decision-making and BMI are linked, which is relevant in understanding entrepreneurial behaviors and actions. Hence, the present study contributes to the IE and BM literature by focusing on the logics of effectuation and causation and highlighting the role of decision-making in the changes that occur through BMI. Thus, our study extends previous research [22] on international SMEs and the IE domain.

Second, we established that effectuation and causation could independently and jointly lead to higher BMI. Most previous studies centered on effectuation and causation, portraying entrepreneurial decision-making as conceptually and operationally opposite based on the assumption that entrepreneurs make either causal or effectual decisions [13]. In dynamic environments, the combination of causation and effectuation boosts an SME's innovative capability compared with the sole focus on planning or control of events [10, 24]. As recent studies have shown, this leverage effect may only be present in stable international environments [72].

The present study expands the previous research by demonstrating some factors that influence the extent of effectuation may also have a similar effect on causation in the same manner [50]. Thus, we contribute to the literature by shedding light on the relationship between effectuation, causation, and BMI in internationalizing SMEs. Our findings indicate that entrepreneurial behavior and choices influence the BM changes that firms make and affect how they approach international opportunities and foreign markets. We agree with previous scholars who suggested that linking BMI and decision-making $[10,39,1])$ is crucial in advancing the research because the entrepreneurial ability to master effective decision-making and tactics in response to changing situations and apply their BM fosters unique competitive advantages and successful internationalization.

Third, we extended the theory by identifying the role of internationalization decision-makers as drivers of BM modification. We included decision-making logic in this study, recognizing that the BM that a company uses in one market may not be applicable in international markets. Moreover, in the internationalization process of firms, entrepreneurs may take different routes to implement or exploit opportunities [18, 8]. This study acknowledges that opportunity discovery and exploitation are pivotal and have a central role in determining SME decision-making on both individual and firm levels, which affects the BM. Therefore, a firm's decision-making mechanism determines the extent to which a BM can be adapted to accommodate market dynamics and/or uncertainties in the international market $[73,8,1]$. Notably, the findings of our study showed that entrepreneurs, in general, are becoming more aware of the value of BMI and that the implementation of BMI matters in gaining a long-term competitive advantage. Consequently, managers could navigate causal and effectual thinking and apply both preemptive and predictive strategies in their implementation activities (e.g., R\&D, technological innovation, BMI, and experimentation) to ameliorate competitive and international performances $[73,55,10]$.

Furthermore, we acknowledge that in practice, entrepreneurs are required to make favorable and knowledgeable decisions to facilitate BMI and company performance [35]. However, because of cognitive and structural constraints, making decisions that lead to BMI is an ambiguous, tactical, and risky task [35, 45]. The present exploration of entrepreneurs' effectual and causal logics and how their choices influence value appropriation has made a promising contribution to the international entrepreneurship research on BMI [1]. Thus, understanding the role of managerial decisions that affect firm operations and reactions to customer needs has provided in-depth insights into the dynamics of BMI $[9,12,35]$. Moreover, studies suggest that entrepreneurs should seek to create a dynamic business model that is capable of ensuring the smooth running of existing activities and flexible enough to be receptive to changes in the environment [19]. Entrepreneurs should also seek to develop competences to effectively manage the interaction effect of both logics (as organizational ambidexterity) in their decision making to ensure that they leverage contingencies that are fruitful for their business model [59].

Ultimately, we conclude that although a good BM is essential for international success [7], dynamic managerial capabilities can be further enabled by developing a nexus of decision-making, integrating customer needs, capitalizing on resources and capabilities, and leveraging network ties. These allow firms to develop a non-replicable and successful BM [7, $9,17,74]$. Hence, selecting the appropriate BM to satisfy the firm's needs takes time, and managers need to make informed decisions to continually develop a viable BM.

In summation, effectual and causal logic does not have to be oppositional or mutually exclusive $[25,10]$. Therefore, SMEs would be successful if they had a balanced perception of internationalization choices, embraced flexibility, experimented, learned from industry activities, and cooperated with partners or competitors $[7,57,75]$. Overall, executive 
actions that control and predict may influence the BM design that a firm adopts to ensure long-lasting competitive advantages in international markets.

\section{Future Research Directions}

This study contributes to both business model and IE literature by examining effectuation, causation, and how the combined effects of these logics influence business model innovation as SMEs internationalize. However, given that most previous studies that explored decision-making and $B M$ have been quantitative or experimental. Decision-making might be better understood using a qualitative approach. Indepth qualitative studies (e.g., case studies) comparing BMI elements and value dimensions or mechanisms could yield more finely grained information about the co-dependency of effectuation and BMI over time. Such studies would deepen our understanding of cause-and-effect relationships in both theory and practice due to a firm's strategic choices $[15,25]$. We hope the theory-driven propositions in the present study pave the way for future empirical studies and the recognition that testing propositions using qualitative and quantitative data collected from internationalizing SMEs could yield fruitful results.

Another avenue for future studies would be to use empirical data to further test and verify our propositions in a contextual setting. Longitudinal changes (especially in the development process) in business models and the use of effectuation and causation could be examined in future studies. Similarly, many potential variables could be included in examining the relationships between decision-making logics and internationalization. For instance, the institutional home and host market environments could influence [75] the extent to which the two different logics were developed and utilized by internationally operating enterprises. The empirical data collected in a home market context with little institutional upheaval might be restricted in its generalizability across large and emerging markets. Thus, future studies could extend the conceptual model's testing and the relationships to a study based on empirical data collected in such countries.

Finally, although previous studies have acknowledged that effectuation and causation are valuable tools for opportunity exploration and exploitation and strategic choices [71, 30, 16], only a few empirical studies have investigated the linkages between BMs and SMEs' decision-making logic when they seek international opportunities. Future studies should investigate effectuation and causation as organizational ambidexterity and the effect as firms change and develop their business model over time or even in unique industrial contexts. Such studies could lead to valuable insights into entrepreneurial cognition and how entrepreneurs respond to international opportunities.

A complementary caveat in our study is the recognition that the "new normal" has led to new business approaches in our present-day and age. Individuals are bounded by rationality, but the use of digital tools and algorithms (e.g., artificial intelligence) has begun to blur these lines [68]. More than ever before, firms can predict and control market economics. Future studies could explore how the new normal, new technology, digitalization, and artificial intelligence tools may revolutionize the way we do business in the future.

\section{References}

[1] F. Futterer, J. Schmidt, and S. Heidenreich, "Effectuation or Causation as the Key to Corporate Venture Success? Investigating Effects of Entrepreneurial Behaviors on Business Model Innovation and Venture Performance“, Long Range Planning, 51(1), 2018, pp. 64-81.

[2] G.A. Alsos, T.H. Clausen, R. Mauer, S. Read, and S.D. Sarasvathy, "Effectual Exchange: From Entrepreneurship to the Disciplines and Beyond", Small Business Economics, 2019, pp.1-15.

[3] A. Zucchella, B. Hagen, and M. Serapio, International Entrepreneurship. Cheltenham: Edward Elgar Publishing Limited, 2018, pp. 37-67.

[4] S.D. Sarasvathy, "Causation and Effectuation: Toward a Theoretical Shift from Economic Inevitability to Entrepreneurial Contingency", Academy of Management Review, 26(2), 2001, pp. 243-263.

[5] S. Shane, "Prior Knowledge and the Discovery of Entrepreneurial Opportunities", Organization Science, 11(4), 2000, pp. 448-469.

[6] H.J. Sapienza, E. Autio, G. George, and S.A. Zahra, "A capabilities perspective on the effects of early internationalization on firm survival and growth", Academy of Management Review, 31(4), 2006, pp. 914-933.

[7] D.J. Teece, "Business Models, Business Strategy, and Innovation”, Long Range Planning, 43(2-3), 2010, pp. 172-194.

[8] J. Child, L. Hsieh, S. Elbanna, J. Karmowska, S. Marinova, P. Puthusserry, T. Tsai, R. Narooz, and Y. Zhang, "SME International Business Models: The Role of Context and Experience", Journal of World Business, 2017.

[9] S.M. Shafer, H.J. Smith, and J.C. Linder, "The Power of Business Models. Business Horizons, 48(3), 2005, pp. 199-207.

[10] M.K. Sitoh, S.L. Pan, and C.Y. Yu, "Business Models and Tactics in New Product Creation: The Interplay of Effectuation and Causation Processes", IEEE Transactions on Engineering Management, 61(2), 2014, pp. 213-224.

[11] Ø.D. Fjeldstad and C.C. Snow, "Business Models and Organization Design", Long Range Planning, 51(1), 2018, pp. 32-39.

[12] P. Gabrielsson and M. Gabrielsson, "A Dynamic Model of Growth Phases and Survival in International Business-ToBusiness New Ventures: The Moderating Effect of DecisionMaking Logic", Industrial Marketing Management, 42(8), 2013, pp. 1357-1373.

[13] R. Harms and H. Schiele, "Antecedents and Consequences of Effectuation and Causation in the International New Venture Creation Process", Journal of International Entrepreneurship, 10(2), 2012, pp. 95-116.

[14] A. Onetti, A. Zucchella, M.V. Jones, and P.P. McDougallCovin, "Internationalization, Innovation, and Entrepreneurship: Business Models for New Technology-based Firms", Journal of Management and Governance, 16(3), 2012, pp. 337-368.

[15] L.M. Sainio, S. Saarenketo, N. Nummela, and T. Eriksson, "Value Creation of an Internationalizing Entrepreneurial Firm: The Business Model Perspective", Journal of Small Business and Enterprise Development, 18(3), 2011, pp. 556-570.

[16] G. Fisher, "Effectuation, Causation, and Bricolage: A Behavioral Comparison of Emerging Theories in Entrepreneurship Research", Entrepreneurship Theory and Practice, 36(5), 2012, pp. 1019-1051.

[17] J.F. Hennart, "The Accidental Internationalists: A Theory of Born Globals", Entrepreneurship Theory and Practice, 38(1), 2014, pp. 117-135.

[18] C. Velu and A. Jacob, "Business model innovation and ownermanagers: the moderating role of competition", R\&D 
Management, 46(3), 2016, pp. 451-463. Zahra, SA, and George, G. (2002). International entrepreneurship: The current status of the field and future research agenda. Strategic entrepreneurship: Creating a new Mindset, 255-288.

[19] S. Cavalcante, P. Kesting, and J. Ulhøi, "Business Model Dynamics and Innovation: (Re)Establishing the Missing Linkages", Management Decision, 49(8), 2011, 1327-1342.

[20] S.A. Cavalcante, "Designing Business Model Change", International Journal of Innovation Management, 18(02), 2014, p. 1450018.

[21] S.A. Zahra, M. Wright, and S.G. Abdelgawad, "Contextualization and the Advancement of Entrepreneurship Research", International Small Business Journal, 32(5), 2014, pp. $479-500$.

[22] L. Torkkeli, H. Salojärvi, L-M. Sainio, and S. Saarenketo, "Do All Roads Lead to Rome? The Effect of Decision-Making Logic on Business Model Change", Journal of Entrepreneurship, Management, and Innovation, 11(3), 2015, pp. 5-24.

[23] A. Asemokha, J. Musona, L. Torkkeli, and S. Saarenketo, "Business Model Innovation and Entrepreneurial Orientation Relationships in SMEs: Implications for International Performance", Journal of International Entrepreneurship, 17(3), 2019, 425-453.

[24] N. Nummela, S. Saarenketo, P. Jokela, and S. Loane, "Strategic Decision-Making of a Born Global: A Comparative Study from Three Small Open Economies", Management International Review, 54, 2014, pp. 527-550.

[25] H. Guo, J. Tang, Z. Su, and J.A. Katz, "Opportunity Recognition and SME Performance: The Mediating Effect of Business Model Innovation”, R\&D Management, 47(3), 2017, pp. 431-442.

[26] A. Osterwalder, Y. Pigneur, and C.L. Tucci, "Clarifying Business Models: Origins, Present, and Future of the Concept", Communications of the Association for Information Systems, 16(1), 2005, p. 1.

[27] M.W. Johnson, C.M. Christensen, and H. Kagermann, "Reinventing Your Business Model", Harvard Business Review, 86(12), 2008, pp. 57-68.

[28] T. Galkina and S. Chetty, "Effectuation and Networking of Internationalizing SMEs", Management International Review, 55(5), 2015, pp. 647-676.

[29] S. Prashantham, K. Kumar, S. Bhagavatula, and S.D. Sarasvathy, "Effectuation, Network-Building and Internationalisation Speed", International Small Business Journal, 37(1), 2019, pp. 3-21.

[30] J. T. Perry, G.N. Chandler, and G. Markova, "Entrepreneurial Effectuation: A Review and Suggestions for Future Research", Entrepreneurship Theory and Practice, 36(4), 2012, pp. 837861.

[31] E. Maine, P.H. Soh, and N. Dos Santos, "The Role of Entrepreneurial Decision-Making in Opportunity Creation and Recognition", Technovation, 39, 2015, pp. 53-72.

[32] C. Zott, R. Amit, and L. Massa, "The Business Model: Recent Developments and Future Research", Journal of Management 37(4), 2011, pp. 1019-1042.

[33] G. Pohle and M. Chapman, "IBM's Global CEO Report 2006: Business Model Innovation Matters", Strategy and Leadership, 34(5), 2006, pp. 34-40

[34] D. Schneckenberg, V. K. Velamuri, C. Comberg, and P. Spieth, "Business Model Innovation and Decision Making: Uncovering Mechanisms for Coping with Uncertainty", R\&D Management, 47(3), 2017, pp. 404-419.

[35] R. Amit and C. Zott, "Value Creation in E-business", Strategic Management Journal, 22(6-7), 2001, pp. 493-520.

[36] S. Shane, and S. Venkataraman, "The Promise of Entrepreneurship as a Field of Research", Academy of Management Review, 25(1), 2000, pp. 217-226.
[37] B.M. Oviatt and P.P. McDougall, "Defining International Entrepreneurship and Modeling the Speed of Internationalization", Entrepreneurship Theory and Practice, 29(5), 2005, pp. 537-553.

[38] I. Reymen, H. Berends, R. Oudehand, and R. Stultiëns, "Decision Making for Business Model Development: A Process Study of Effectuation and Causation in New Technology-Based Ventures", R\&D Management, 47(4), 2017, pp. 595-606.

[39] N.J. Foss and T. Saebi, "Fifteen Years of Research on Business Model Innovation: How Far Have We Come, and Where Should We Go?” J. Manag. 43(1), 2017, pp. 200-227.

[40] B. Demil and X. Lecocq, "Business Model Evolution: In Search of Dynamic Consistency", Long Range Planning, 43, 2010, pp. 227-246.

[41] P. Spieth and S. Schneider, "Business Model Innovativeness: Designing a Formative Measure for Business Model Innovation", Journal of Business Economics, 86(6), 2016, pp. 671-696.

[42] T. Saebi, L. Lien, and N.J. Foss, 2016 "What Drives Business Model Adaptation? The Impact of Opportunities, Threats and Strategic Orientation", Long Range Planning.

[43] M. Rask, "Internationalization Through Business Model Innovation: In Search of Relevant Design Dimensions and Elements", Journal of International Entrepreneurship, 12(2), 2014, pp. 146-161.

[44] R. Amit and C. Zott, "Creating Value Through Business Model Innovation", M.I.T. Sloan Management Review, 53(3), 2012, pp.41-49.

[45] T. Clauss, "Measuring Business Model Innovation: Conceptualization, Scale Development, and Proof of Performance", R\&D Management, 47(3), 2017, pp. 385-403.

[46] R.G. McGrath, "Business Models: A Discovery Driven Approach. Long Range Planning, 43(2-3), 2010, pp. 247-261.

[47] R. Casadesus-Masanell and F. Zhu, "Business Model Innovation and Competitive Imitation: The Case of Sponsorbased Business Model", Strategic Management Journal, 34, 2013, pp. 464-482.

[48] L. Massa, C.L. Tucci, and A. Afuah, "A Critical Assessment of Business Model Research", Academy of Management Annals, 11(1), 2017, pp. 73-104.

[49] G.N. Chandler, D.R. DeTienne, A. McKelvie, and T.V. Mumford, "Causation and Effectuation Processes: A Validation Study", Journal of Business Venturing, 26(3), 2011, pp. 375390.

[50] G.T. Lumpkin and G.G. Dess, 1996 "Enriching the Entrepreneurial Orientation Construct: A Reply to Entrepreneurial Orientation or Pioneer Advantage",

[51] M. Sosna, R.N. Trevinyo-Rodríguez, and S.R. Velamuri "Business Model Innovation Through Trial-and-Error Learning: The Naturhouse Case", Long Range Plan 43(2-3), 2010, pp. 383-407

[52] S.D. Sarasvathy, Effectuation: Elements of Entrepreneurial Expertise. Edward Elgar, Northampton, 2008.

[53] N. Dew, S. Read, S.D. Sarasvathy, and R. Wiltbank, "Effectual Versus Predictive Logics in Entrepreneurial Decision-Making: Differences Between Experts and Novices", Journal of Business Venturing, 24(4), 2009, pp. 287-309.

[54] C. Baden-Fuller and M.S. Morgan, "Business Models as Models“, Long-Range Planning, 43(2-3), 2010, pp. 156-171.

[55] S. Andersson, "International Entrepreneurship, Born Globals, and the Theory of Effectuation", Journal of Small Business and Enterprise Development, 18(3), 2011, pp.627-643.

[56] I. Kalinic, S.D. Sarasvathy, and C. Forza, "'Expect the Unexpected": Implications of Effectual Logic on the Internationalization Process", International Business Review, 23(3), 2014, pp. 635-647.

[57] T. Galkina, and E.L. Lundgren-Henriksson, "Coopetition As an Entrepreneurial Process: Interplay of Causation and 
Effectuation”, Industrial Marketing Management, 67, 2017, pp. 158-173.

[58] E. Autio and I. Zander, "Lean Internationalization", In Academy of Management Proceedings (Vol. 2016, No. 1, p. 17420). Briarcliff Manor, NY 10510: Academy of Management, 2016.

[59] X. Yu, Y. Tao, X. Tao, F. Xia, and Y. Li, "Managing uncertainty in emerging economies: The interaction effects between causation and effectuation on firm performance", Technological Forecasting and Social Change, 135, 2018, pp. 121-131.

[60] Y. Luo, and H. Rui, "An ambidexterity perspective toward multinational enterprises from emerging economies", Academy of Management Perspectives, 23(4), 2009, pp. 49-70.

[61] S. Raisch, and J. Birkinshaw, "Organizational ambidexterity: Antecedents, outcomes, and moderators", Journal of management, 34(3), 2008, pp. 375-409.

[62] M. Agogue, M. Lundqvist, and K.W. Middleton, "Mindful deviation through combining causation and effectuation: A design theory-based study of technology entrepreneurship", Creativity and Innovation Management, 24(4), 2015, pp. 629644.

[63] K.M. Smolka, I. Verheul, K. Burmeister-Lamp, and P.P. Heugens, "Get it together! Synergistic effects of causal and effectual decision-making logics on venture performance", Entrepreneurship Theory and Practice, 42(4), 2018, pp. 571604.

[64] S.D. Sarasvathy, N. Dew, S. Read, and R. Wiltbank, "Designing Organizations That Design Environments: Lessons from Entrepreneurial Expertise", Organization Studies, 29(3), 2008, pp. 331-350.

[65] S.A. Zahra, "A Theory of International New Ventures: A Decade of Research", Journal of International Business Studies, 36(1), 2005, pp. 20-28.

[66] F. Hacklin and M. Wallnöfer, "The Business Model in the Practice of Strategic Decision Making: Insights from a Case Study”, Management Decision, 50(2), 2012, pp. 166-188.

[67] W.C. Kim, and R. Mauborgne, "Creating New Market Space", Harvard Business Review, 77(1), 1999, pp. 83-93.

[68] I.I. Vadana, L. Torkkeli, O. Kuivalainen, and S. Saarenketo, "Digitalization of companies in international entrepreneurship and marketing", International Marketing Review, 37(3), 2019, 471-492.

[69] S. Schneider and P. Spieth, "Business Model Innovation: Towards an Integrated Future Research Agenda", International Journal of Innovation Management, 17(01), 2013, p. 1340001.

[70] M. Gruber, "Uncovering the Value of Planning in New Venture Creation: A Process and Contingency Perspective", Journal of Business Venturing, 22(6), 2007, pp. 782-807

[71] H. Chesbrough, "Business Model Innovation: Opportunities and Barriers", Long-Range Planning, 43(2-3), 2010, pp. 354363.

[72] J. Vanderstraeten, J. Hermans, A. van Witteloostuijn, and M. Dejardin, "SME Innovativeness in a Dynamic Environment: Is There Any Value in Combining Causation and Effectuation?", Technology Analysis and Strategic Management, 2020, pp. 117.

[73] J. Magretta, "Why Business Models Matter", Harvard Business Review, 80(5), 2002, pp. 86-92.

[74] A. Asemokha, L. Torkkeli, A. R. Faroque, and S. Saarenketo, "Business Model Innovation in International Performance: The Mediating Effect of Network Capability", International Journal of Export Marketing, 3(4), 2020, pp. 290-313.

[75] I. Laine and T. Galkina, "The Interplay of Effectuation and Causation in Decision Making: Russian S.M.E.S Under Institutional Uncertainty", International Entrepreneurship and Management Journal, 13(3), 2017, pp. 905-941. 